\title{
Synthesis and Structure of Tricarbonylchromium Mono-, Bis- and Tris- Complexes of 10-Methyltribenzotriquinacene
}

\author{
Alberto Ceccon, ${ }^{*, a}$ Alessandro Gambaro, ${ }^{a}$ Francesco Manoli, ${ }^{b}$ Alfonso Venzo, ${ }^{b}$ Dietmar Kuck, \\ Thomas E. Bitterwolf, ${ }^{d}$ Paolo Ganis ${ }^{\theta}$ and Giovanni Valle ${ }^{f}$ \\ a Dipartimento di Chimica Fisica and ${ }^{b}$ CNR, Centro Studi Stati Molecolari Radicalici Eccitati, Via Loredan \\ 2, 35131 Padova, Italy \\ c'Fakultät für Chemie, Universität Bielefeld, Universitätsstrasse 25, 4800 Bielefeld 1, Federal Republic of \\ Germany \\ dDepartment of Chemistry, University of Idaho, Moscow, ID 83843, USA \\ e Dipartimento di Chimica, Università di Napoli, Via Mezzocannone 4, 80134 Napoli, Italy \\ f CNR, Centro di Studio sui Biopolimeri, Via Marzolo 3, 35131 Padova, Italy
}

\begin{abstract}
Complexation of 10-methyltribenzotriquinacene (MTBT) a bent triarene of $C_{3 v}$ symmetry afforded six mono-, bis- and tris- $\operatorname{Cr}(\mathrm{CO})_{3}$ complexed isomers which have been isolated and identified. The results of various synthetic experiments indicate that complexation at the convex side of a free benzene ring is favoured, probably for steric reasons. As compared with the isomer complexed at the convex face (anti), that complexed at the concave one (syn) is less stable. The ${ }^{1} \mathrm{H}$ and ${ }^{13} \mathrm{C}$ NMR spectral data together with the $\mathrm{X}$-ray structures of the two bis- and one tris-complexes account for the lower stability of the $s y n$ isomers.
\end{abstract}

$\eta^{6}$-Arene- $\mathrm{Cr}(\mathrm{CO})_{3}$ complexes have been studied extensively in a wide variety of applications. ${ }^{1}$ The effects of complexation of a benzene moiety with $\mathrm{Cr}(\mathrm{CO})_{3}$ range from the facility of nucleophilic alkylation reactions ${ }^{2}$ to the easy abstraction of benzylic protons. ${ }^{3}$ Their use as asymmetric reagents has also been investigated. ${ }^{4}$ Since the $\mathrm{Cr}(\mathrm{CO})_{3}$ unit can be easily removed from the arene at the end of the synthetic sequence these complexes have also become increasingly interesting in organic synthesis. ${ }^{1 c}$

The vast majority of arene ligands coordinated with $\mathrm{Cr}(\mathrm{CO})_{3}$ have a monocyclic planar structure, the general interest in
$\mathrm{Cr}(\mathrm{CO})_{3}$ complexes of fused planar polycyclic hydrocarbons being evident from the rapidly expanding literature on this topic. ${ }^{5}$ On the other hand, there are only few references to studies in the area of bent di- or poly-arenes. The complexation of 9,10-etheno- and 9,10-ethano-anthracene, for example, has shown that these bent diarenes can be coordinated on either the convex (anti) or concave (syn) faces of the ligand. ${ }^{6}$ Biscomplexation of the same hydrocarbons yielded the trans isomer as the major species, but cis dimetallation of the convex faces has also been observed. The crystal structures of syn and anti-Cr(CO) $)_{3}$ isomers of 9,10 -ethanoanthracene have recently

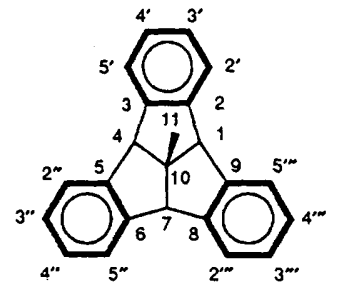

MTBT $^{2}$

\begin{tabular}{|c|c|c|c|c|}
\hline \multirow[b]{2}{*}{ complex } & \multirow[b]{2}{*}{$\log 0^{b}$} & \multicolumn{3}{|c|}{ Benzene ring labels } \\
\hline & & $\begin{array}{c}\text { free } \\
\text { benzo }\end{array}$ & $\begin{array}{c}\text { anti-Cr(CO) } \\
\text {-benzo } \\
\end{array}$ & $\begin{array}{c}s y n-\operatorname{Cr}\left(\mathrm{CO}_{3}\right. \\
\text {-benzo }\end{array}$ \\
\hline 1 anti- $-\mathrm{Cr}(\mathrm{CO})_{3}$ & & 'and'" & " & \\
\hline $2 s y n-\mathrm{Cr}\left(\mathrm{CO}_{3}\right.$ & & "and"" & & , \\
\hline 3 anti,syn $-\left[\mathrm{Cr}(\mathrm{CO})_{3}\right]_{2}$ & & "” & $"$ & ' \\
\hline 4 anti,anti- $-\left[\mathrm{Cr}(\mathrm{CO})_{3}\right]_{2}$ & & , & "and"" & \\
\hline 5 anti, anti,syn-[Cr(CO) $)_{3}$ & & & "and"' & ' \\
\hline 6 anti, anti, anti $-\left[\mathrm{Cr}(\mathrm{CO})_{3}\right]_{3}$ & & & 'and" and"' & \\
\hline
\end{tabular}

Fig. 1 Schematic view of the products of the complexation of MTBT with $\mathrm{Cr}(\mathrm{CO})_{3} \mathrm{~L}_{3}$ in ethers. ${ }^{a}$ The numbering of MTBT as a triquinacene derivative is used through this work as shown here for clarity. ${ }^{b}$ Filled and empty circles indicate anti- and $s y n-\mathrm{Cr}(\mathrm{CO})_{3}$ groups, respectively. 
Table 1 Complexation products of free and $\mathrm{Cr}(\mathrm{CO})_{3}$-complexed MTBT

\begin{tabular}{|c|c|c|c|c|c|c|c|c|c|}
\hline \multirow[b]{2}{*}{$\operatorname{Run}^{a}$} & \multirow[b]{2}{*}{ Substrate } & \multirow{2}{*}{$\begin{array}{l}\mathrm{Cr}(\mathrm{CO})_{6}: \text { substrate } \\
\text { (moles) }\end{array}$} & \multirow[b]{2}{*}{$t / \mathrm{h}$} & \multicolumn{6}{|c|}{ Yield of recovered products $(\%)^{b}$} \\
\hline & & & & 1 & 2 & 3 & 4 & 5 & 6 \\
\hline $1^{b}$ & MTBT & $3.6: 1$ & 40 & 45 & - & 25 & 19 & 1 & - \\
\hline 2 & MTBT & $1: 1$ & 19 & 40 & 8 & 1 & 2 & - & - \\
\hline 3 & MTBT & $1: 2$ & 8 & 40 & 7 & trace & trace & - & - \\
\hline 4 & 1 & $2: 1$ & 2 & 70 & - & 5.5 & 21 & 1.6 & 0.5 \\
\hline 5 & 1 & $3: 1$ & 24 & 45 & - & 5.5 & 40 & 3.2 & 1.7 \\
\hline 6 & 2 & $3: 1$ & 2 & 22 & 10 & 50 & 6 & 8 & - \\
\hline 7 & 3 & $2: 1$ & 2 & 7 & - & 65 & 3 & 25 & - \\
\hline $8^{c}$ & 4 & $2: 1$ & 24 & - & - & - & - & 50 & 50 \\
\hline $9^{d}$ & MTBT & $1: 1$ & 6 & 38 & 0.5 & 10 & 4 & 1 & - \\
\hline
\end{tabular}

${ }^{a}$ Runs 1-8: solvent, butyl ether: THF $90: 10 \mathrm{v} / \mathrm{v} ; T 146{ }^{\circ} \mathrm{C}$. ${ }^{b}$ Yields in runs $1-3$ and 9 are isolated yields and refer to the free ligand; in runs 4-8 yields were calculated from NMR spectra. The free ligand was isolated or detected by NMR spectroscopy to the extent of the difference to $10 \%^{\circ} \cdot{ }^{c}$ Very similar results were obtained when a $1: 2$ ratio was used. ${ }^{d}$ Reaction carried out in refluxing dioxane using $\left(\mathrm{CH}_{3} \mathrm{CN}\right)_{3} \mathrm{Cr}(\mathrm{CO})_{3}$ as the $\mathrm{Cr}(\mathrm{CO})_{3}$ source.

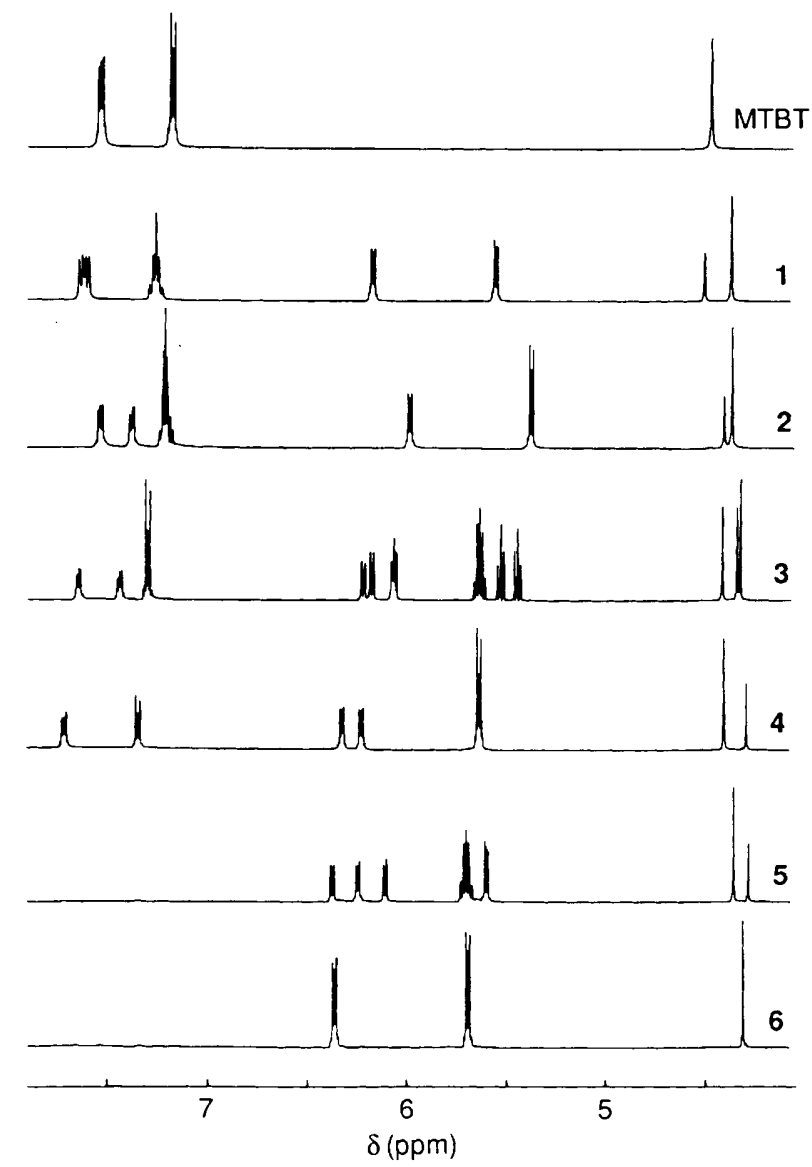

Fig. $2{ }^{1} \mathrm{H}$ NMR spectra of the free and $\mathrm{Cr}(\mathrm{CO})_{3}$-complexed MTBTs Solvent $\left[{ }^{2} \mathrm{H}_{6}\right]$ acetone; $T 298 \mathrm{~K} ; v_{0}, 400.13 \mathrm{MHz} ; \delta$ in ppm from internal $\mathrm{Me}_{4} \mathrm{Si}$. The methyl proton signal is omitted.

been reported by Traylor et al. ${ }^{7}$ in the course of studies on neighbouring group participation in arene-exchange reactions.

A few years ago, one of us ${ }^{8}$ reported the facile synthesis of 10 methyltribenzotriquinacene (MTBT), a bent triarene of $C_{3 \mathrm{v}}$ symmetry. MTBT is a member of a new series of rigid polycyclic aromatic hydrocarbons. ${ }^{9}$ Complexation with $\mathrm{Cr}(\mathrm{CO})_{3}$ of MTBT can afford mono-, bis- and tris-complexed isomers. In this paper we describe the syntheses and the X-ray structures of the complexes obtained by reaction of MTBT with $\mathrm{Cr}(\mathrm{CO})_{3} \mathrm{~L}_{3}$ $\left(\mathrm{L}=\mathrm{CO}, \mathrm{CH}_{3} \mathrm{CN}\right)$ and discuss the molecular structures of the resulting compounds.

\section{Results}

The tricarbonylchromium complexes 1-6 of 10-methyltri- benzotriquinacene (see Fig. 1) were prepared by boiling the free hydrocarbon and $\operatorname{Cr}(\mathrm{CO})_{6}$ in a 90:10 v/v mixture of butyl ether-tetrahydrofuran (THF). Separation of the complexes was accomplished by medium pressure column chromatography on silica under argon, as described in the Experimental section.

By working with an excess of the complexing agent and prolonged reaction times (Table 1, run 1) we obtained high conversion of MTBT into four different complexes $(1,3,4$ and 5$)$ which were isolated in the indicated yields as yellow crystalline air-stable solids. On the basis of the NMR and mass spectra, and on X-ray measurements (see below), they have been identified as anti- $\mathrm{Cr}(\mathrm{CO})_{3}-\mathrm{MTBT} 1$, anti,syn- $\left[\mathrm{Cr}(\mathrm{CO})_{3}\right]_{2}-$ MTBT 3, anti,anti-[Cr(CO) $\left.]_{3}\right]_{2}-\mathrm{MTBT} 4$ and anti,anti,syn$\left[\mathrm{Cr}(\mathrm{CO})_{3}\right]_{3}-\mathrm{MTBT} 5$. In order to drive the reaction towards mono-complexation, an excess of MTBT over $\mathrm{Cr}(\mathrm{CO})_{6}$ and shorter reaction times were used in runs 2 and 3 . In these experiments (conversion $\mathrm{ca} .60 \%$ ) the anti-Cr(CO) $)_{3}$ isomer 1 was still the main product but a ca. $8 \%$ yield of the syn- $\mathrm{Cr}(\mathrm{CO})_{3}$ isomer 2 could be isolated. The formation of bis- and triscomplexed products was negligible.

Reaction of 1 with $\mathrm{Cr}(\mathrm{CO})_{6}$ (run 4) gave, besides the bis- and tris-complexed species obtained in run 1 , small quantities of a new tris-metallated complex, viz. anti,anti,anti- $\left[\mathrm{Cr}(\mathrm{CO})_{3}\right]_{3}-$ MTBT 6, the yield of which increased with the reaction time (run 5). The syn- $\mathrm{Cr}(\mathrm{CO})_{3}$ isomer 2 is more reactive towards $\mathrm{Cr}(\mathrm{CO})_{6}(\mathrm{ca} .90 \%$ conversion in $2 \mathrm{~h}$, run 6$)$, the main products being 3 and 1; significant amounts of 4 and 5 were also recovered. Complex 3 also exhibited appreciable reactivity towards $\mathrm{Cr}(\mathrm{CO})_{6}(35 \%$ conversion in $2 \mathrm{~h}$, run 7$)$, the product being mainly 5 . In contrast, complex 4 is practically unreactive under the same conditions, and only after prolonged reaction times ( $c f$. run 8 ) was it completely converted into the isomers 5 and 6 in a ratio of $1: 1$. Finally, when $\left(\mathrm{CH}_{3} \mathrm{CN}\right)_{3} \mathrm{Cr}(\mathrm{CO})_{3}$ in refluxing dioxane was used as complexing agent (run 9), all the complexes except 6 were obtained.

NMR Measurements.-The ${ }^{1} \mathrm{H}$ and ${ }^{13} \mathrm{C}$ NMR spectra of 1-6 have been used for identification (see Fig. 2). The proton assignment was performed by selective decoupling and $\left\{{ }^{1} \mathrm{H}\right\}-{ }^{1} \mathrm{H}$ NOE measurements. The proton chemical shifts for each molecule are listed in Table 2 . The ${ }^{13} \mathrm{C}$ NMR resonances were attributed to the corresponding nuclei by selectively decoupled and partially relaxed spectra, and they are reported in Table 3 together with the ${ }^{1} J_{\mathrm{C}-\mathrm{H}}$ values. Proton-proton coupling constants for MTBT, 1, 2, 3, 4,5 and 6 are filed as supplementary material, sup. No. 56801 (3 pp).*

The ligand MTBT. The spectrum of MTBT exhibits a sharp

* For details of supplementary publication scheme see 'Instructions for Authors (1991),'J. Chem. Soc., Perkin Trans. 2, 1991, Issue 1. 
Table $2{ }^{1}$ H NMR parameters ${ }^{a}$ for MTBT and complexes 1-6

\begin{tabular}{|c|c|c|c|c|c|c|c|}
\hline \multirow[b]{2}{*}{$\mathbf{H}(i)$} & \multicolumn{7}{|c|}{ Chemical shifts, ${ }^{b} \delta_{i}$} \\
\hline & МТBT & 1 & 2 & 3 & 4 & 5 & 6 \\
\hline 1 & 4.470 & 4.506 & 4.363 & 4.410 & 4.401 & 4.357 & 4.311 \\
\hline 4 & 4.470 & 4.370 & 4.363 & 4.317 & 4.401 & 4.357 & 4.311 \\
\hline 7 & 4.470 & 4.370 & 4.402 & 4.335 & 4.291 & 4.281 & 4.311 \\
\hline 11 & 1.676 & 1.750 & 1.625 & 1.714 & 1.819 & 1.795 & 1.865 \\
\hline $2^{\prime}$ & 7.535 & 7.602 & 5.981 & 6.052 & 7.710 & 6.238 & 6.359 \\
\hline $3^{\prime}$ & 7.179 & 7.271 & 5.376 & 5.527 & 7.342 & 5.601 & 5.693 \\
\hline $4^{\prime}$ & 7.179 & 7.248 & 5.376 & 5.444 & 7.342 & 5.601 & 5.693 \\
\hline $5^{\prime}$ & 7.535 & 7.632 & 5.981 & 6.165 & 7.710 & 6.238 & 6.359 \\
\hline $2^{\prime \prime}$ & 7.535 & 6.169 & 7.375 & 6.062 & 6.217 & 6.102 & 6.359 \\
\hline $3^{\prime \prime}$ & 7.179 & 5.561 & 7.205 & 5.623 & 5.630 & 5.688 & 5.693 \\
\hline $4^{\prime \prime}$ & 7.179 & 5.561 & 7.218 & 5.643 & 5.633 & 5.711 & 5.693 \\
\hline $5^{\prime \prime}$ & 7.535 & 6.169 & 7.533 & 6.210 & 6.314 & 6.366 & 6.359 \\
\hline $2^{\prime \prime \prime}$ & 7.535 & 7.632 & 7.533 & 7.640 & 6.314 & 6.366 & 6.359 \\
\hline $3^{\prime \prime \prime}$ & 7.179 & 7.248 & 7.218 & 7.293 & 5.633 & 5.711 & 5.693 \\
\hline $4^{\prime \prime \prime}$ & 7.179 & 7.271 & 7.205 & 7.294 & 5.630 & 5.688 & 5.693 \\
\hline $5^{\prime \prime \prime}$ & 7.535 & 7.602 & 7.375 & 7.434 & 6.217 & 6.102 & 6.359 \\
\hline
\end{tabular}

${ }^{a} T 298 \mathrm{~K}$, solvent $\left[{ }^{2} \mathrm{H}_{6}\right]$ acetone, internal standard $\mathrm{Me}_{4} \mathrm{Si}$. Values obtained by computer simulation. For proton labelling see Fig. 1. The $J_{i, j}$ coupling constant values are deposited as Supplementary material. ${ }^{b}$ The uncertainties in $\delta$ are $\leq 0.001 \mathrm{ppm}$.

singlet due to the methyl protons and a moderately broadened singlet for the methine nuclei. Besides these signals, an $\mathbf{A A}^{\prime} \mathbf{B B}^{\prime}$ pattern due to the aromatic protons lies in the range of 7.6-7.1 $\mathrm{ppm}$. The lower field components are slightly broadened by a small coupling constant with the methine nuclei, so they are attributed to the $\mathrm{H}\left(2^{\prime}, 5^{\prime}, 2^{\prime \prime}, 5^{\prime \prime}, 2^{\prime \prime \prime}, 5^{\prime \prime \prime}\right)$ protons, and the assignments were confirmed by NOE experiments. These data agree with those reported in the literature. ${ }^{8}$

Mono-complexes 1 and 2. Besides a sharp singlet at $c a .1 .7$ ppm due to the methyl proton resonance, the ${ }^{1} \mathrm{H}$ NMR spectra of 1 and 2 consist of an ABCD system between $\delta_{\mathbf{H}} 7.6$ and 7.1 (8 protons overall) attributed to the uncomplexed ring protons on the basis of the chemical shift values, the integral ratio, and the molecular symmetry. An $\mathrm{AA}^{\prime} \mathbf{B B}^{\prime}$ pattern (4 protons) belonging to the complexed benzo ring is found between $\delta_{H} 6.2$ and 5.6 for 1 and between 6.0 and $5.3 \mathrm{ppm}$ for 2 . Finally, two different resonances in $1: 2$ integral ratio due to the methine protons are folind in the range of $\delta_{\mathrm{H}} 4.5-4.3$, as expected. The number of signals in the proton decoupled ${ }^{13} \mathrm{C}$ NMR spectra are consistent with the molecular symmetry of the two complexes, the most important difference being the marked downfield shift of the quaternary carbon atom resonance of the complexed ring of $\mathbf{2}$ in comparison with the corresponding signal of $\mathbf{1}$. In addition, the $\mathrm{C} \equiv \mathrm{O}$ resonance of $1\left(\delta_{\mathrm{C}} 234.87\right)$ appears at a significant lower field than that of $2\left(\delta_{\mathrm{C}} 232.58\right)$.

Bis-complexes 3 and 4 . The ${ }^{1} \mathrm{H}$ NMR spectrum of the firsteluted bis-complexed MTBT, 3, indicates the absence of molecular symmetry. In fact, three $A B C D$ patterns ( 4 protons each) were found in the ranges of $\delta_{\mathbf{H}} 7.6-7.1,6.2-5.5$ and 6.0-5.3; three different methine resonances are present at $\delta_{\mathrm{H}} 4.41,4.32$ and 4.28. In addition, all the 23 carbon nuclei of the MTBT ligand are clearly distinguished in the ${ }^{13} \mathrm{C}$ spectrum, and two different signals for the $\mathrm{C} \equiv \mathrm{O}$ carbons are observed at $\delta_{\mathrm{C}} 234.83$ and 232.65. These results clearly indicate that the two $\mathrm{Cr}(\mathrm{CO})_{3}$ units are coordinated one to the convex and the other to the concave side of the ligand (see the X-ray structure below). The spectrum of $\mathbf{4}$, on the contrary, indicates a symmetrical molecular structure in agreement with the $C_{\mathrm{s}}$ symmetry found by crystallography. In fact, an $\mathrm{AA}^{\prime} \mathbf{B B}^{\prime}$ spin system (4 protons) was found in the region of $\delta_{\mathrm{H}} 7.8-7.3$, and is attributed to the uncomplexed ring protons. In addition, an ABCD spin system ( 8 protons) attributed to the complexed ring protons appears between 6.4 and $5.6 \mathrm{ppm}$, and two singlets for the methine nuclei in the integral ratio $2: 1$ are found at 4.40 and $4.29 \mathrm{ppm}$. The molecular geometry is confirmed also by the number and $\delta$ values of the ${ }^{13} \mathrm{C}$ resonances of the organic portion of 4 . The equivalence of the two $\mathrm{Cr}(\mathrm{CO})_{3}$ groups is confirmed by the single signal observed for the carbonyl carbon atoms at $\delta_{\mathrm{C}}$ 234.32 .

Tris-complexes 5 and $\mathbf{6}$. The spectrum of 5 reflects the same symmetry as that of 4 . The resonances attributed to the free ring of 4 are now shifted upfield, as expected upon complexation, to $\delta$ values different from those found for the complexed portion of 4 , suggesting that the third $\mathrm{Cr}(\mathrm{CO})_{3}$ unit is coordinated to the concave side of MTBT. This is confirmed by the two resonances found for the $\mathrm{C} \equiv \mathrm{O}$ carbon atoms at $\delta_{\mathrm{C}} 234.30$ and 232.82 in the integral ratio $2: 1$, respectively. By comparison with the $\mathrm{X}$-ray data 5 was characterized as the anti,anti,syn- $\left[\mathrm{Cr}(\mathrm{CO})_{3}\right]_{3}-$ MTBT. On the contrary, the proton and carbon NMR spectra of 6 show the presence of three equivalent $\mathrm{Cr}(\mathrm{CO})_{3}$-coordinated benzo rings, as indicated by the single $\mathbf{A A}^{\prime} \mathbf{B B}^{\prime}$ pattern for the aromatic protons occurring between 6.3 and $5.7 \mathrm{ppm}$, together with only one methine resonance at $4.31 \mathrm{ppm}$. In addition to the equivalence of the aromatic and methine carbon atoms, only one signal for the $\mathrm{C} \equiv \mathrm{O}$ carbon atoms is found in the ${ }^{13} \mathrm{C}$ spectrum $\delta_{\mathrm{C}} 233.86$.

X-Ray Measurements.-Satisfactory crystals for diffractometric analysis were obtained by slow evaporation under an inert atmosphere of concentrated solutions of 3,4 and 5 in a $1: 1: 1$ mixture of acetone, methanol and methylene chloride. The other complexes decompose in this medium, and no good crystals were obtained from other solvent mixtures. Perspective views of the complexes $\mathbf{3 , 4}$ and $\mathbf{5}$ are shown in Fig. 3 (retaining the same numbering system for all three). Selected crystal data for the complexes 3,4 and 5 , and the fractional coordinates of the non- $\mathrm{H}$ atoms are given in Tables 5 and 6, respectively, and will be discussed separately in detail below.

The X-ray analysis of 3 showed that one of the two $\mathrm{Cr}(\mathrm{CO})_{3}$ units is bonded to the convex side of the organic ligand and the other to the concave one. The two metal groups in 4 are both bonded in equivalent positions to the convex side of MTBT, that is, in the anti,anti position. The molecule exhibits a mirror plane which bisects the free ring and comprises the $C_{10}$ and the $\mathrm{C}_{\text {:itethyl }}$ carbon atoms. The tris-complexed 5 exhibits two types of coordinated $\mathrm{Cr}(\mathrm{CO})_{3}$ groups, that is, two equivalent metal units are bonded to the convex side of MTBT, and the third one to the concave side.

\section{Discussion}

The results summarized in Table 1 indicate that the complexation with $\mathrm{Cr}(\mathrm{CO})_{3}$ at the convex side of a free benzene ring is favoured both in the reaction of MTBT and that of complexes 1 and 2, the trend being observed for all the experimental conditions used. For example, an anti/syn preference of $c a$. five can be estimated from the products ratios $1: 2$ in runs 2 and 3, and $4: 3$ in run 5 . This is in contrast with the previous results obtained by complexation with $\mathrm{Cr}(\mathrm{CO})_{3}$ of the bent diarene dibenzo[2.2.2] bicyclooctane where syn coordination is the preferred one in the absence of a directing group. ${ }^{6}$ Probably, the presence of a third benzo ring in MTBT makes the concave side of the framework too sterically unfavourable to the attack of the metal, despite its enhanced electron density. Nevertheless, complex 2 should be formed as an intermediate when MTBT is reacted with excess $\mathrm{Cr}(\mathrm{CO})_{6}$. In fact, it was not isolated among the reaction products of run 1, but the formation of 2 was observed after short reaction times by TLC analysis. Obviously, this species is rapidly consumed in the course of the reaction with $\mathrm{Cr}(\mathrm{CO})_{6}$ to give mostly complex 3 . In this respect, the results of run 6 are instructive. When 2 is used as the substrate 
Table $3{ }^{13} \mathrm{C}$ NMR chemical shifts ${ }^{a} \delta(\mathrm{ppm})$ and ${ }^{1} J_{\mathrm{CH}} / \mathrm{Hz}$ (in parentheses) for MTBT and complexes 1-6

\begin{tabular}{|c|c|c|c|c|c|c|c|}
\hline $\mathrm{C}(i)$ & MTBT & 1 & 2 & 3 & 4 & 5 & 6 \\
\hline \multirow[t]{2}{*}{1} & 63.36 & 64.39 & 62.31 & 61.27 & 63.37 & 61.28 & 62.44 \\
\hline & $(132.2)$ & (136.1) & (133.3) & (138.6) & (138.6) & (139.2) & (141.8) \\
\hline \multirow[t]{2}{*}{4} & 63.36 & 63.34 & 62.31 & 63.21 & 63.37 & 61.28 & 62.44 \\
\hline & $(132.2)$ & (138.2) & (133.3) & (137.3) & (138.6) & (139.2) & (141.8) \\
\hline 7 & $\begin{array}{r}63.36 \\
(132.2)\end{array}$ & $\begin{array}{r}63.34 \\
(138.2)\end{array}$ & $\begin{array}{r}64.14 \\
(138.6)\end{array}$ & $\begin{array}{r}62.31 \\
(135.7)\end{array}$ & $\begin{array}{r}62.42 \\
(141.4)\end{array}$ & $\begin{array}{r}62.34 \\
(1416)\end{array}$ & $\begin{array}{r}62.44 \\
(1418)\end{array}$ \\
\hline \multirow[t]{2}{*}{10} & 61.13 & 61.33 & 62.03 & 62.10 & 61.40 & $\begin{array}{r}(141.6) \\
62.07\end{array}$ & $\begin{array}{r}(141.8) \\
61.40\end{array}$ \\
\hline & $(-)$ & $(-)$ & $(-)$ & $(-)$ & $(-)$ & $(-)$ & $(-)$ \\
\hline \multirow[t]{2}{*}{11} & 27.83 & 27.73 & 28.12 & 28.01 & 27.73 & 28.13 & 27.83 \\
\hline & $(125.9)$ & (125.9) & $(126.5)$ & (126.8) & (126.5) & (127.6) & (129.3) \\
\hline \multirow[t]{2}{*}{2} & 146.42 & 146.34 & 124.37 & 124.72 & 144.49 & 120.96 & 115.27 \\
\hline & $(-)$ & $(-)$ & $(-)$ & $(-)$ & $(-)$ & $(-)$ & $(-)$ \\
\hline \multirow[t]{2}{*}{$2^{\prime}$} & 125.34 & 125.60 & 90.78 & 91.74 & 125.85 & 91.27 & 91.10 \\
\hline & $(158.9)$ & $(157.7)$ & $(172.3)$ & $(173.6)$ & $(160.2)$ & $(176.5)$ & (174.1) \\
\hline \multirow[t]{2}{*}{$3^{\prime}$} & 128.19 & 129.20 & 92.01 & 93.15 & 129.58 & 93.32 & 95.05 \\
\hline & $(155.1)$ & (159.3) & $(174.8)$ & $(174.5)$ & $(157.7)$ & $(173.2)$ & (176.4) \\
\hline \multirow[t]{2}{*}{$4^{\prime}$} & 128.19 & 128.61 & 92.01 & 92.19 & 129.58 & 93.32 & 95.05 \\
\hline & $(155.1)$ & $(159.7)$ & $(174.8)$ & $(175.6)$ & $(157.7)$ & $(173.2)$ & $(176.4)$ \\
\hline \multirow[t]{2}{*}{$5^{\prime}$} & 125.34 & 125.56 & 90.78 & 91.20 & 125.85 & 91.27 & 91.10 \\
\hline & $(158.9)$ & $(156.9)$ & $(172.3)$ & $(174.2)$ & $(160.2)$ & $(176.5)$ & (174.1) \\
\hline \multirow[t]{2}{*}{3} & 146.42 & 144.47 & 124.37 & 120.56 & 144.49 & 120.96 & 115.27 \\
\hline & $($ 一) & $(-)$ & $(-)$ & $(-)$ & $(-)$ & $(-)$ & $(-)$ \\
\hline \multirow[t]{2}{*}{$\mathrm{C}^{\prime} \equiv \mathrm{O}$} & - & - & 232.58 & 232.65 & - & 232.82 & 233.86 \\
\hline & $(-)$ & $(-)$ & $(-)$ & $(-)$ & $(-)$ & $(-)$ & $(-)$ \\
\hline \multirow[t]{2}{*}{5} & 146.42 & 118.09 & 145.44 & 117.60 & 117.94 & 117.12 & 115.27 \\
\hline & $(-)$ & $(-)$ & $(-)$ & $(-)$ & $(-)$ & $(-)$ & $(-)$ \\
\hline \multirow[t]{2}{*}{$2^{\prime \prime}$} & 125.34 & 91.26 & 125.21 & 90.84 & 90.97 & 91.07 & 91.10 \\
\hline & $(158.9)$ & $(175.5)$ & $(156.4)$ & $(174.2)$ & $(175.1)$ & $(174.7)$ & (174.1) \\
\hline \multirow[t]{2}{*}{$3^{\prime \prime}$} & 128.19 & 94.86 & 128.20 & 94.74 & 94.68 & 95.10 & 95.05 \\
\hline & $(155.1)$ & $(175.5)$ & (159.5) & $(175.1)$ & $(175.8)$ & (176.2) & (176.4) \\
\hline \multirow[t]{2}{*}{$4^{\prime \prime}$} & 128.19 & 94.86 & 128.78 & 95.39 & 95.23 & 95.21 & 95.05 \\
\hline & (155.1) & $(175.5)$ & $(158.8)$ & $(174.9)$ & (175.3) & (175.7) & (176.4) \\
\hline \multirow[t]{2}{*}{$5^{\prime \prime}$} & 125.34 & 91.26 & 125.34 & 91.74 & 91.58 & 91.67 & 91.10 \\
\hline & (158.9) & $(175.5)$ & $(157.7)$ & $(173.6)$ & (173.4) & $(177.1)$ & (174.1) \\
\hline \multirow[t]{2}{*}{6} & 146.42 & 118.09 & 146.99 & 117.68 & 115.33 & 114.92 & 115.27 \\
\hline & $(-)$ & $(-)$ & $(-)$ & $(-)$ & $(-)$ & $(-)$ & $(-)$ \\
\hline \multirow[t]{2}{*}{$\mathrm{C}^{\prime \prime} \equiv \mathrm{O}$} & - & 234.87 & - & 234.83 & 234.32 & 234.30 & 233.86 \\
\hline & $(-)$ & $(-)$ & $(-)$ & $(-)$ & $(-)$ & $(-)$ & $(-)$ \\
\hline 8 & 146.42 & 144.47 & 146.99 & 143.56 & 115.33 & 114.92 & 115.27 \\
\hline $2^{\prime \prime \prime}$ & $\begin{array}{l}(--) \\
125.34\end{array}$ & $(-)$ & $(-)$ & $\left(-\frac{1}{125.62}\right.$ & $(-)$ & $(-)_{91.67}$ & $\stackrel{(-)}{91.10}$ \\
\hline & (158.9) & $(156.9)$ & $(157.7)$ & $(160.3)$ & (173.4) & $(177.1)$ & (174.1) \\
\hline $3^{\prime \prime \prime}$ & 128.19 & 128.61 & 128.78 & 129.18 & 95.23 & 95.21 & 95.05 \\
\hline & (155.1) & (159.7) & $(158.8)$ & $(160.4)$ & (175.3) & $(175.7)$ & (176.4) \\
\hline $4^{\prime \prime \prime}$ & 128.19 & 129.20 & 128.20 & 129.23 & 94.68 & 95.10 & 95.05 \\
\hline & $(155.1)$ & (159.3) & $(159.5)$ & (159.4) & $(175.8)$ & $(176.2)$ & (176.4) \\
\hline $5^{\prime \prime \prime}$ & 125.34 & 125.60 & 125.21 & 125.29 & 90.97 & 91.07 & 91.10 \\
\hline & $(158.9)$ & $(157.7)$ & (156.4) & (161.1) & (175.1) & $(174.7)$ & (174.1) \\
\hline 9 & 146.42 & 146.34 & 145.44 & 146.74 & 117.94 & 117.12 & 115.27 \\
\hline & $(--)$ & $(-)$ & $(-)$ & $(-)$ & $(-)$ & $(-)$ & $(-)$ \\
\hline $\mathrm{C}^{\prime \prime \prime} \equiv \mathrm{O}$ & - & - & - & - & 234.32 & 234.30 & 233.86 \\
\hline & $(-)$ & $(-)$ & $(-)$ & $(-)$ & $(-)$ & $(-)$ & $(-)$ \\
\hline
\end{tabular}

${ }^{a} T 298 \mathrm{~K}$; solvent $\left[{ }^{2} \mathrm{H}_{6}\right]$ acetone; internal standard $\mathrm{Me}_{4} \mathrm{Si}$; for carbon labelling see Fig. 1 . The uncertainties in $\delta$ and ${ }^{1} J_{\mathrm{CH}}$ are $\leq 0.03 \mathrm{ppm}$ and $\pm 0.3 \mathrm{~Hz}$, respectively. The assignments of $C\left(3^{\prime \prime \prime}\right)$ and $C\left(4^{\prime \prime \prime}\right)$ in 4 can be reversed.

$90 \%$ of it is consumed within two hours to give complexes 3 and 5 , which both originate from subsequent anti attacks, and also considerable amounts of complexes 1 and 4 . The formation of the latter two products suggest that $\mathrm{a} \operatorname{Cr}(\mathrm{CO})_{3}$ unit is expelled relatively easily when complexed to the concave face of MTBT. However, as shown in runs 2 and 3, complex 2 is stable enough to be isolated after reaction of $\mathrm{Cr}(\mathrm{CO})_{6}$ with excess MTBT.

Comparison of runs 6 and 4 shows that the syn complex 2 is markedly more reactive than the anti isomer 1 towards further complexation. Whereas 2 reacts readily to give 3 and 5 , in which the syn- $\mathrm{Cr}(\mathrm{CO})_{3}$ group is preserved, isomer 1 gives mainly the anti,anti-[ $\left.\mathrm{Cr}(\mathrm{CO})_{3}\right]_{2}$ complex 4 , particularly after prolonged reaction times (run 5). The considerable yields of 3 obtained in run 6 , as well as that of 5 obtained from 3 (run 7), suggest that MTBT complexes containing a $s y n-\mathrm{Cr}(\mathrm{CO})_{3}$ group are stabilized by $\mathrm{Cr}(\mathrm{CO})_{3}$ units added to the convex face of the organic moiety. This is supported by the finding that further complexation of 4 occurs with similar effectiveness at both faces of the MTBT ligand (run 8).

The results discussed above are in accord with the reactions shown in Scheme 1.

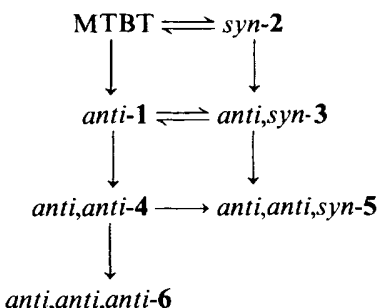

Scheme 1 

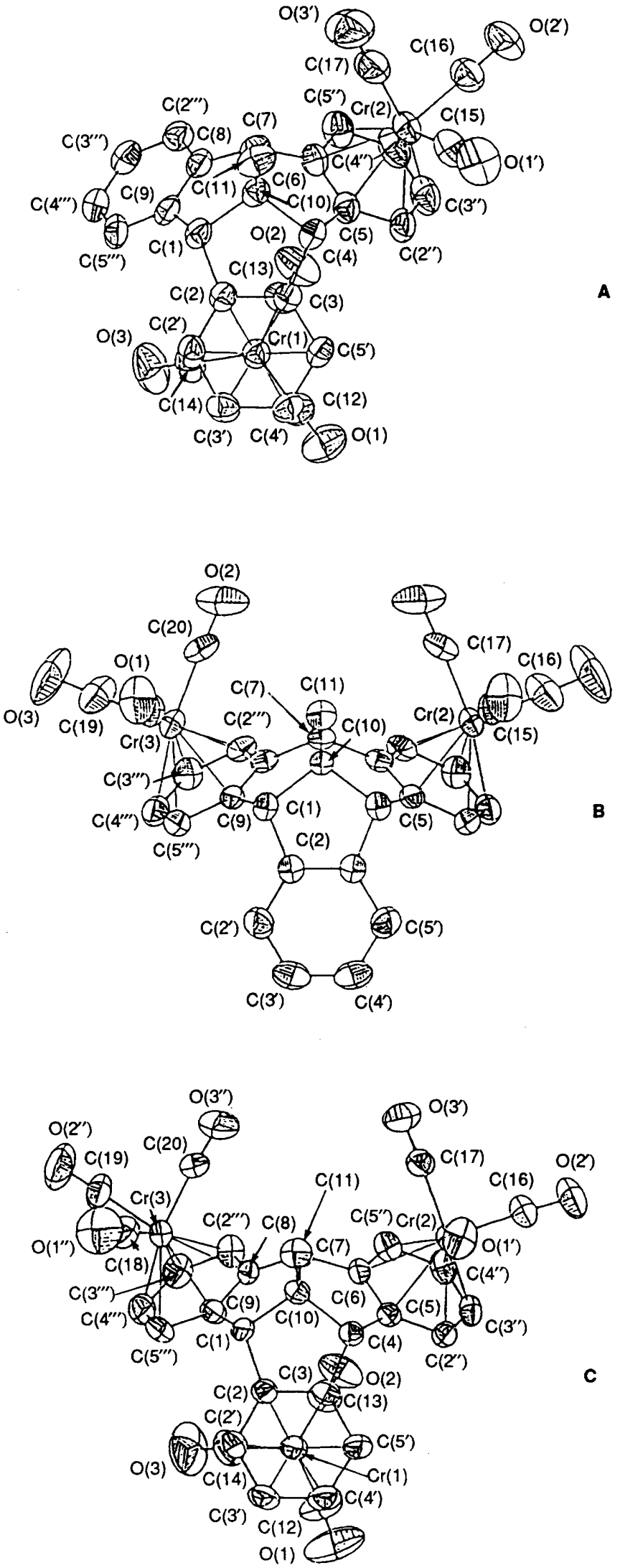

Fig. 3 Projection of the molecules of 3,4 and 5(A, B and C, respectively) as viewed down the normal to the benzene ring $\left[\mathrm{C}(2), \mathrm{C}\left(2^{\prime}\right), \mathrm{C}\left(3^{\prime}\right), \mathrm{C}\left(4^{\prime}\right)\right.$, $\mathrm{C}\left(5^{\prime}\right)$ and $\left.\mathrm{C}(3)\right]$

As compared with the anti- $\mathrm{Cr}(\mathrm{CO})_{3}$ complex 1 , the lower stability found for the syn isomer 2 may be ascribed to a repulsive interaction between the oxygen carbonyl atoms and the $\pi$ electron cloud of the adjacent benzene ring. This effect

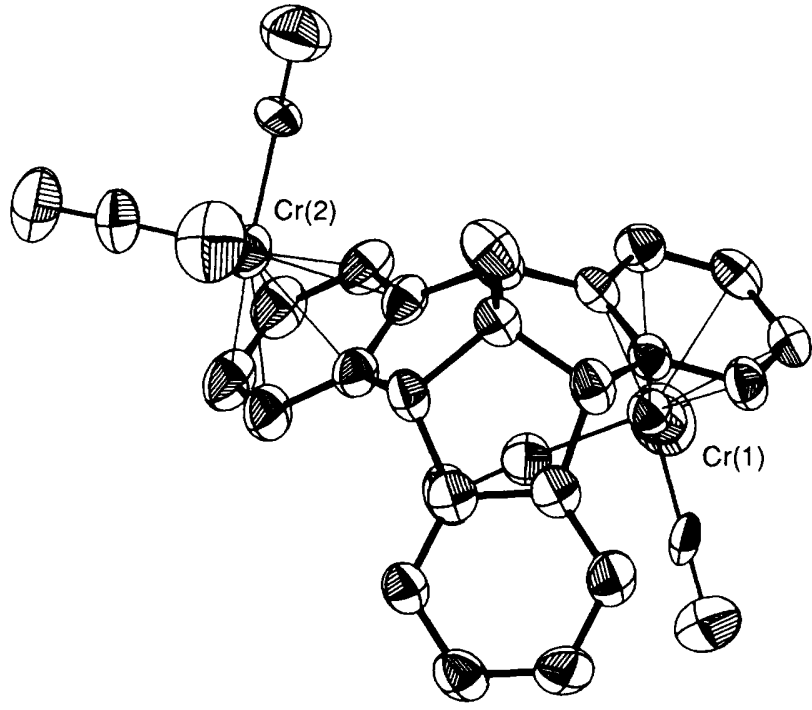

Fig. 4 A perspective view of the molecule of 3 showing the two $\mathrm{Cr}(\mathrm{CO})_{3}$ groups on opposite sides of the hydrocarbon

appears to vanish on further complexation, probably by an energetically more favoured interaction between the oxygen atoms and the anti-coordinated benzene ring. This hypothesis is supported by the crystallographic results obtained for the biscomplexed anti,syn-3 and the tris-complexed anti,anti,syn-5 (see below).

$X$-ray Data.-Selected geometrical parameters of the 3, 4 and 5 complexes are given in Tables 5, 7 and 8 .

We turn first to the discussion to the structure of the anti,anticomplex 4 . The molecule lies on a crystallographic mirror plane (Fig. 3B). The structurally independent $\mathrm{Cr}(\mathrm{CO})_{3}$ group is in the usual ${ }^{*}$ exo conformation, and it is rotated $\mathrm{ca} .10^{\circ}$ about the chromium-arene bond from an idealized 'staggered' conformation (see Table 7), giving rise to distances from the $\mathrm{C}(20)-\mathrm{O}(2)$ and $\mathrm{C}(18)-\mathrm{O}(1)$ bond middle points to $\mathrm{H}(7)$ and $\mathrm{H}(1)$ of $c a .2 .90$ and $3.05 \AA$, respectively (see Table 5). The $\mathrm{Cr}$ atom lies almost exactly on the central normal to its complexed benzene ring. Similarly to other analogous complexes, ${ }^{11}$ the average $\mathrm{C}_{\mathrm{Ar}}-\mathrm{C}_{\mathrm{Ar}}$ bond distance for the complexed rings $[1.405(6) \AA]$ is slightly longer than that for the uncomplexed ring $[1.383(6) \AA]$. The geometrical parameters of the organic framework are, within the error limits, the same as those found for the free ligand except for a widened dihedral angle $\angle \beta \gamma=$ $122^{\circ}$ (see Table 8 ), between the least square planes containing the two complexed indan residues. The widening from $c a .116^{\circ}$ (as found for the free ligand ${ }^{12}$ ) cannot be ascribed to steric factors; it is likely to be due to complexation effects.

The molecular structure of the anti,syn-complex $\mathbf{3}$ is shown in Fig. $3 \mathrm{~A}$, and an additional perspective view which clearly shows the two $\mathrm{Cr}(\mathrm{CO})_{3}$ groups on opposite sides of the hydrocarbon is given in Fig. 4. The conformation of the anti $\mathrm{Cr}(\mathrm{CO})_{3}$ group is still exo, and a rotation of $c a .13^{\circ}$ is observed about the chromium-arene bond from the staggered orientation (see Table 7). This rotation leads to distances of $c a .2 .8$ and $c a .3 .3$ $\AA$ from the middle points of $\mathrm{C}(17)-\mathrm{O}\left(3^{\prime}\right)$ and $\mathrm{C}(15)-\mathrm{O}\left(1^{\prime}\right)$ bonds to $H(7)$ and $H(4)$, respectively (see Table 5). No evaluable slippage for $\mathrm{Cr}$ was found. In contrast, the conformation of the syn $\mathrm{Cr}(\mathrm{CO})_{3}$ group is almost eclipsed with C-3, C-2' and C-4'. As a consequence, the carbonyl oxygen $\mathrm{O}-2$ is located very close to the central normal to the adjacent anti complexed benzene

* $O$-condensed bicyclic polyene- $\mathrm{ML}_{3}$ compounds may have two conformational extremes, i.e., the endo isomer with one $\mathrm{L}$ group pointing to the interior of the uncoordinated portion of the molecule, and the exo isomer with one $\mathrm{L}$ group bisecting the bond between the outermost carbon atoms. ${ }^{10}$ 
Table 4 Summary of crystal data and intensity collection for complexes 3, 4 and 5

\begin{tabular}{|c|c|c|c|}
\hline Compound & $\begin{array}{l}3 \\
\text { (anti,syn) }\end{array}$ & $\begin{array}{l}4 \\
\text { (anti,anti) }\end{array}$ & $\begin{array}{l}\mathbf{5} \\
\text { (anti,anti,syn) }\end{array}$ \\
\hline Formula & $\mathrm{C}_{29} \mathrm{H}_{18} \mathrm{Cr}_{2} \mathrm{O}_{6}$ & $\mathrm{C}_{29} \mathrm{H}_{18} \mathrm{Cr}_{2} \mathrm{O}_{6}$ & $\mathrm{C}_{32} \mathrm{H}_{18} \mathrm{Cr}_{3} \mathrm{O}_{9}$ \\
\hline $\begin{array}{l}M \\
a / \AA\end{array}$ & $\begin{array}{l}566.443 \\
10.538(6)\end{array}$ & $\begin{array}{l}566.443 \\
21.160(12)\end{array}$ & $\begin{array}{l}702.466 \\
14.470(6)\end{array}$ \\
\hline$b / \AA$ & $23.910(13)$ & $\begin{array}{l}21.160(12) \\
14.530(7)\end{array}$ & $\begin{array}{l}14.470(6) \\
17.250(8)\end{array}$ \\
\hline$c / \AA$ & $9.712(6)$ & $8.023(5)$ & $12.410(6)$ \\
\hline$\beta /^{\circ}$ & $98.8(1)$ & - & $112.7(1)$ \\
\hline$V / \AA^{3}$ & 2418.3 & 2466.7 & 2857.7 \\
\hline$Z$ & 4 & 4 & 4 \\
\hline$D_{\mathrm{c}}$ & 1.56 & 1.53 & 1.66 \\
\hline Space group & $P 2_{1} / n$ & Pmen & $P 2_{1} / n$ \\
\hline Crystal $\mathrm{dim} / \mathrm{mm}$ & $0.3 \times 0.2 \times 0.4$ & $0.2 \times 0.2 \times 0.4$ & $0.3 \times 0.3 \times 0.4$ \\
\hline$T / \mathrm{K}$ & 298 & 298 & 298 \\
\hline Radiation & \multicolumn{3}{|c|}{ graphite-monochromated Mo-K $\alpha(\lambda=0.7107 \AA)$} \\
\hline$\mu / \mathrm{cm}^{-1}$ & 10.45 & 10.25 & 13.17 \\
\hline Take off angle/deg & 3.0 & 3.0 & 3.0 \\
\hline Scan speed/deg $\mathrm{min}^{-1}$ & \multirow{2}{*}{\multicolumn{3}{|c|}{$\begin{array}{c}2.0 \text { in the } 2 \theta \text { scan mode } \\
3.0 \leq 2 \theta \leq 45\end{array}$}} \\
\hline $2 \theta$ range $/ \mathrm{deg}$ & & & \\
\hline Unique data $\left(F_{0}^{2}>2 \sigma\left(F_{0}^{2}\right)\right.$ & 5808 & 3054 & 6896 \\
\hline$R\left(\right.$ on $\left.F_{0}\right)$ & 0.056 & 0.052 & 0.050 \\
\hline
\end{tabular}

ring at a distance of $c a .2 .9 \AA$ from its plane. To our knowledge this constitutes the first example of such a disfavoured conformation and can be explained only in terms of attractive electronic interactions between the hybrid $\mathrm{C} \equiv \mathrm{O}$ orbitals and the $\pi$ system of the anti-complexed benzene ring involved. A small slippage of $\mathrm{Cr}(c a .0 .05 \AA)$ towards $\mathrm{C}^{\prime}$ ' is noted. Here too, we clearly distinguish between $\mathrm{C}_{\mathrm{Ar}}-\mathrm{C}_{\mathrm{Ar}}$ average bond length for complexed rings $[1.403(6) \AA]$ and uncomplexed ring [1.386(6) $\AA]$. In this case, all three dihedral angles between the leastsquare planes defined by the indan moieties are widened with respect to those of the free ligand to values of 119,122 and $126^{\circ}$ (see Table 8). This fact might here also be due to intramolecular steric interaction.

Fig. 3C shows the molecular structure of the anti,anti,syncomplex 5. The conformation of both the anti $\mathrm{Cr}(\mathrm{CO})_{3}$ groups is $e x o$, and they are rotated $c a .10^{\circ}$ in the same sense about the chromium-arene bond from an idealized 'staggered' conformation. As a result we observe distances from the middle points of $\mathrm{C}(15)-\mathrm{O}\left(1^{\prime}\right)$ and $\mathrm{C}(17)-\mathrm{O}\left(3^{\prime}\right)$ bonds to $\mathrm{H}(4)$ and $\mathrm{H}(1)$ of 2.61 and $3.13 \AA$, respectively. This recurring feature is present, albeit to differing extents, in all these (and other similar ${ }^{13}$ ) complexes, and it seems not to be merely coincidental. We believe that here the methine hydrogens undergo a weak $\sigma-\pi$ interaction with the closest $\mathrm{C} \equiv \mathrm{O}$ group. The distinction between the two methine hydrogens at distances from vicinal carbonyl groups $<2.8-2.9$ or $>3.0-3.1 \AA$ is possible in the solid state for stabilizing effects of the crystal field but very likely disappears in solution as shown by NMR spectroscopy (see below). The conformation of the syn $\mathrm{Cr}(\mathrm{CO})_{3}$ group is here almost exactly eclipsed. Here again the carbonyl oxygen atom $O(2)$ lies very close to the central normal to one of the adjacent anti complexed benzene rings at a distance of $c a .2 .9 \AA$ from its plane. Therefore, the more unstable eclipsed conformation appears to be favoured by the same stabilizing interaction between the $O(2)$ atom and the polarized side of the vicinal benzene as hypothesized for 3 , and is thus confirmed. The choice of ring complexed to $\mathrm{Cr}(2)$ rather than the one complexed to $\mathrm{Cr}(3)$ atom is only to be ascribed to packing reasons. A small slippage of $\mathrm{Cr}(1)(\mathrm{ca} 0.06 \AA)$ towards $\mathrm{C}\left(3^{\prime}\right)$ is observed similar to that found in the case of 3 . As all the arene rings are complexed here we observe, as expected, the same average $C_{A_{r}}-C_{A r}$ bond lengths of $1.405(6) \AA$ for them. Two of the dihedral angles between the least-square planes containing the indan moieties are widened to $123-126^{\circ}$ (see Table 8 ) with respect to those of the free ligand, which is also likely to be for steric reasons.
All the other geometrical parameters for 3, 4 and 5 resemble those reported for many tricarbonylchromium complexes ${ }^{11}$ and the ligand. ${ }^{12}$ They do not require any particular comment and are filed as supplementary material.

NMR Results.-Some significant features connected with the greater lability of the syn-coordinated $\mathrm{Cr}(\mathrm{CO})_{3}$ group may result from the comparison of the NMR data of $\mathbf{1}$ and 2 .

The most relevant difference between the anti and syn isomers found in the ${ }^{13} \mathrm{C}$ NMR spectra of 1 and 2 is the considerable downfield shift $\left(\Delta \delta_{C} 6.2\right)$ of the quaternary carbon atoms of the complexed benzene ring of 2 as compared with those of 1 . Conversely, the two outermost carbon atoms of the same ring exhibit an upfield shift of $2.3 \mathrm{ppm}$. Different complexation effects have been also observed in the ${ }^{1} \mathrm{H}$ NMR spectra where the protons of the syn-complexed ring resonate at higher field compared with those of the anti-complexed ring ( $c a .0 .2 \mathrm{ppm}$ ). These complexation effects can be explained by assuming that in the syn-isomer, much more than in the anti-isomer, the chromium atom is shifted away from the quaternary carbons towards the external side of the ring. This explanation is further substantiated by the $X$-ray results obtained for complexes 3 and 5. The extent of slippage, as expressed by the difference between the average of distances of the $\mathrm{Cr}$ atom from the innermost and outermost pairs of carbon atoms, is greater for the syncomplexed ring $(0.040 \AA$ in $3 ; 0.078 \AA$ in 5$)$ than for the anticomplexed ring $(0.019 \AA$ in 3 ; $0.006 \AA$ in 5$)$. The distortion towards an $\eta^{4}$-hapticity exhibited by the $\operatorname{syn}$ - $\mathrm{Cr}(\mathrm{CO})_{3}$ group may be responsible for its tendency to dissociate easily.

Both anti and $s y n$ isomers exhibit a single ${ }^{13} \mathrm{C}$ peak for the metal-bound carbonyl ligand, the resonance being shifted about $2 \mathrm{ppm}$ upfield in the $s y n$-isomer. The resonances at $c a .234 \mathrm{ppm}$ and $c a .232 \mathrm{ppm}$ represent a valuable diagnostic tool which can help to determine the site of complexation. The observation of a single carbonyl peak in both stereoisomers down to $T=183 \mathrm{~K}$ indicates the absence of significant restrictions to the rotation around the $\mathrm{Cr}-\mathrm{C}_{\mathrm{Ar}}$ bond which would lead to a loss in equivalence of these carbon atoms.

The chemical shifts of the protons and carbons of the uncomplexed portion of the ligand are slightly (albeit differently) influenced by the presence of an anti or syn- $\mathrm{Cr}(\mathrm{CO})_{3}$ group and no specific interaction is detectable. These long-range complexation effects remain practically invariant upon coordination of the other rings. Thus, the contributions to the chemical shifts of every nucleus (both ${ }^{1} \mathrm{H}$ and ${ }^{13} \mathrm{C}$ ) from the 
$\mathrm{Cr}(\mathrm{CO})_{3}$ groups co-ordinated to adjacent benzene rings are perfectly additive.

\section{Experimental}

General.--All the reactions and complex manipulations were performed in an oxygen-free argon atmosphere. The solvents were carefully dried and deoxygenated before use and the $\mathrm{Cr}(\mathrm{CO})_{6}$ (Aldrich) was twice sublimed under reduced pressure just before use. Solvent mixtures, reaction times and substrate/complexing agent ratios are given in Table 1. In the preparative experiments (runs 1-3 and 9), the pure products were obtained by repeated chromatography on silica of the residue. All the complexes appear as yellow, air-stable microcrystalline powders, which gave satisfactory elemental analysis. Melting points are uncorrected. Microanalyses were performed by Mr. L. Turiaco, Dipartimento di Chimica Inorganica, Metallorganica ed Analitica, Università di Padova. The IR spectra were recorded as tetrahydrofuran (THF) solutions with a Perkin-Elmer 580B spectrophotometer, and the $70 \mathrm{eV}$ electron impact mass spectra were measured with a VG 16 MicroMass spectrometer.

Complex 1. M.p. $185-190^{\circ} \mathrm{C}$ (decomp.); $v_{\max }(\mathrm{THF}) / \mathrm{cm}^{-1}$ $1968 \mathrm{vs}$ and $1885 \mathrm{vs}(\mathrm{C} \equiv \mathrm{O}) ; m / z 430\left(\mathrm{M}^{+}, 3.1 \%\right), 374\left(\mathrm{M}^{+}-\right.$ $2 \mathrm{CO}, 6.0), 346\left(\mathrm{M}^{+}-3 \mathrm{CO}, 43.8\right), 294\left[\mathrm{M}^{+}-(\mathrm{Cr}, 3 \mathrm{CO}), 100\right]$ and $52\left(\mathrm{Cr}^{+}, 96.1\right)$

Complex 2. M.p. $198-200^{\circ} \mathrm{C}$ (decomp.); $v_{\max }(\mathrm{THF}) / \mathrm{cm}^{-1}$ $1964 \mathrm{vs}, 1897 \mathrm{vs}$ and $1879 \mathrm{vs}(\mathrm{C} \equiv \mathrm{O}) ; \mathrm{m} / z \quad 430\left(\mathrm{M}^{+}, 6.6 \%\right) 374$ $\left(\mathrm{M}^{+}-2 \mathrm{CO}, 6.2\right), 346\left(\mathrm{M}^{+}-3 \mathrm{CO}, 100\right), 294\left[\mathrm{M}^{+}-(\mathrm{Cr}\right.$, $3 \mathrm{CO}), 5.5]$ and $52\left(\mathrm{Cr}^{+}, 3.5\right)$.

Complex 3. M.p. $170^{\circ} \mathrm{C}$ (decomp.); $v_{\max }(\mathrm{THF}) / \mathrm{cm}^{-1} 1961 \mathrm{vs}$ and 1883 vs $(\mathrm{C} \equiv \mathrm{O}) ; m / z 566\left(\mathrm{M}^{+}, 4.9\right), 510\left(\mathrm{M}^{+}-2 \mathrm{CO}, 3.0\right)$, $482\left(\mathrm{M}^{+}-3 \mathrm{CO}, 8.8\right), 454\left(\mathrm{M}^{+}-4 \mathrm{CO}, 3.5\right), 430\left[\mathrm{M}^{+}-(\mathrm{Cr}\right.$, $3 \mathrm{CO}), 4.1], 426\left(\mathrm{M}^{+}-5 \mathrm{CO}, 4.5\right), 398\left(\mathrm{M}^{+}-6 \mathrm{CO}, 9.4\right), 374$

Table 5 Selected bond lengths and intramolecular interatomic distances $/ \AA$

\begin{tabular}{|c|c|c|c|}
\hline Atoms & $\begin{array}{l}3 \\
(\text { anti,syn) }\end{array}$ & $\begin{array}{l}4 \\
\text { (anti,anti) }\end{array}$ & $\begin{array}{l}\mathbf{5} \\
\text { (anti,anti,syn) }\end{array}$ \\
\hline $\mathrm{Cr}(1)-\mathrm{C}(2)$ & $2.267(4)$ & - & $2.264(4)$ \\
\hline $\mathrm{Cr}(1)-\mathrm{C}(2)^{\prime}$ & $2.227(5)$ & - & $2.203(4)$ \\
\hline $\mathrm{Cr}(1)-\mathrm{C}(3)^{\prime}$ & $2.227(5)$ & - & $2.196(4)$ \\
\hline $\mathrm{Cr}(1)-\mathrm{C}(4)^{\prime}$ & $2.210(5)$ & - & $2.201(5)$ \\
\hline $\mathrm{Cr}(1)-\mathrm{C}(5)^{\prime}$ & $2.245(5)$ & - & $2.239(4)$ \\
\hline $\mathrm{Cr}(1)-\mathrm{C}(3)$ & $2.249(4)$ & - & $2.288(4)$ \\
\hline $\mathrm{Cr}(2)-\mathrm{C}(5)$ & $2.231(4)$ & $2.236(8)$ & $2.215(3)$ \\
\hline $\mathrm{Cr}(2)-\mathrm{C}(2)^{\prime \prime}$ & $2.214(5)$ & $2.266(7)$ & $2.226(4)$ \\
\hline $\mathrm{Cr}(2)-\mathrm{C}(3)^{\prime \prime}$ & $2.221(6)$ & $2.224(9)$ & $2.214(4)$ \\
\hline $\mathrm{Cr}(2)-\mathrm{C}(4)^{\prime \prime}$ & $2.194(5)$ & $2.198(9)$ & $2.211(4)$ \\
\hline $\mathrm{Cr}(2)-\mathrm{C}(5)^{\prime \prime}$ & $2.229(6)$ & $2.210(8)$ & $2.206(4)$ \\
\hline $\mathrm{Cr}(2)-\mathrm{C}(6)$ & $2.222(5)$ & $2.212(8)$ & $2.223(4)$ \\
\hline $\mathrm{Cr}(3)-\mathrm{C}(8)$ & - & $2.212(8)$ & $2.216(5)$ \\
\hline $\mathrm{Cr}(3)-\mathrm{C}(2)^{\prime \prime \prime}$ & - & $2.210(8)$ & $2.228(5)$ \\
\hline $\mathrm{Cr}(3)-\mathrm{C}(3)^{\prime \prime \prime}$ & - & $2.198(9)$ & $2.203(5)$ \\
\hline $\mathrm{Cr}(3)-\mathrm{C}(4)^{\prime \prime \prime}$ & -- & $2.224(9)$ & $2.198(5)$ \\
\hline $\mathrm{Cr}(3)-\mathrm{C}(5)^{\prime \prime \prime}$ & - & $2.226(7)$ & $2.216(5)$ \\
\hline $\mathrm{Cr}(3)-\mathrm{C}(9)$ & - & $2.236(8)$ & $2.234(5)$ \\
\hline $\mathrm{O}(2)-\mathrm{C}(5)$ & $3.21(1)$ & - & $3.37(1)$ \\
\hline $\mathrm{O}(2)-\mathrm{C}(2)^{\prime \prime}$ & $3.34(2)$ & - & $3.56(1)$ \\
\hline $\mathrm{O}(2)-\mathrm{C}(3)^{\prime \prime}$ & $3.41(2)$ & - & $3.58(1)$ \\
\hline $\mathrm{O}(2)-\mathrm{C}(4)^{\prime \prime}$ & $3.42(1)$ & - & $3.43(1)$ \\
\hline $\mathrm{O}(2)-\mathrm{C}(5)^{\prime \prime}$ & $3.33(2)$ & - & $3.25(2)$ \\
\hline $\mathrm{O}(2)-\mathrm{C}(6)$ & $3.23(1)$ & $-\cdots$ & $3.19(1)$ \\
\hline${ }^{a} \mathrm{M}(1)^{\prime}-\mathrm{H}(4)$ & 3.29 & 3.05 & 2.90 \\
\hline${ }^{a} \mathrm{M}(3)^{\prime}-\mathrm{H}(7)$ & 2.82 & 2.90 & 3.02 \\
\hline${ }^{a} \mathrm{M}(3)^{\prime \prime}-\mathrm{H}(7)$ & $\cdots$ & 2.90 & 2.61 \\
\hline${ }^{a} \mathbf{M}(1)^{\prime \prime}-\mathbf{H}(1)$ & - & 3.05 & 3.13 \\
\hline
\end{tabular}

${ }^{a} \mathrm{M}(n)$ indicates the location of the middle point of the corresponding $\mathrm{C} \equiv \mathrm{O}(n)$ group.
Table 6 Fractional coordinates of the non-hydrogen atoms

\begin{tabular}{|c|c|c|c|}
\hline Atom & $x$ & $y$ & $z$ \\
\hline \multicolumn{4}{|c|}{ Complex 3} \\
\hline $\operatorname{Cr}(1)$ & $0.50747(6)$ & $0.21069(3)$ & $0.59500(7)$ \\
\hline $\operatorname{Cr}(2)$ & $0.88078(7)$ & $0.01873(3)$ & $0.71611(9)$ \\
\hline$O(1)$ & $0.6115(4)$ & $0.2927(2)$ & $0.4080(5)$ \\
\hline$O(2)$ & $0.7767(4)$ & $0.2104(2)$ & $0.7420(5)$ \\
\hline $\mathrm{O}(3)$ & $0.4786(4)$ & $0.3055(2)$ & $0.7867(5)$ \\
\hline $\mathrm{O}(1)^{\prime}$ & $0.7832(4)$ & $-0.0557(2)$ & $0.4775(5)$ \\
\hline $\mathrm{O}(2)^{\prime}$ & $1.1383(4)$ & $-0.0360(2)$ & $0.7401(6)$ \\
\hline $\mathrm{O}(3)^{\prime}$ & $0.8084(5)$ & $-0.0682(2)$ & $0.9104(6)$ \\
\hline $\mathrm{C}(1)$ & $0.4371(4)$ & $0.1029(2)$ & $0.8114(4)$ \\
\hline$C(2)$ & $0.4122(4)$ & $0.1351(2)$ & $0.6766(4)$ \\
\hline$C(3)$ & $0.4933(4)$ & $0.1169(2)$ & $0.5824(4)$ \\
\hline $\mathrm{C}(4)$ & $0.5775(4)$ & $0.0695(2)$ & $0.6429(4)$ \\
\hline$C(5)$ & $0.7207(4)$ & $0.0804(2)$ & $0.6747(5)$ \\
\hline$C(6)$ & $0.7645(4)$ & $0.0792(2)$ & $0.8178(5)$ \\
\hline$C(7)$ & $0.6572(4)$ & $0.0679(2)$ & $0.8994(4)$ \\
\hline $\mathrm{C}(8)$ & $0.6232(4)$ & $0.1171(2)$ & $0.9831(4)$ \\
\hline$C(9)$ & $0.5006(4)$ & $0.1365(2)$ & $0.9355(4)$ \\
\hline $\mathrm{C}(10)$ & $0.5374(4)$ & $0.0568(2)$ & $0.7876(4)$ \\
\hline C(11) & $0.4834(5)$ & $-0.0024(2)$ & $0.7923(5)$ \\
\hline $\mathrm{C}(12)$ & $0.5695(5)$ & $0.2609(2)$ & $0.4796(5)$ \\
\hline$C(13)$ & $0.6718(5)$ & $0.2077(2)$ & $0.6857(6)$ \\
\hline $\mathrm{C}(14)$ & $0.4875(5)$ & $0.2693(2)$ & $0.7126(6)$ \\
\hline$C(15)$ & $0.8213(5)$ & $-0.0276(2)$ & $0.5692(6)$ \\
\hline$C(16)$ & $1.0376(5)$ & $-0.0156(2)$ & $0.7289(6)$ \\
\hline $\mathrm{C}(17)$ & $0.8383(6)$ & $-0.0349(3)$ & $0.8367(7)$ \\
\hline $\mathrm{C}(2)^{\prime}$ & $0.3205(4)$ & $0.1766(2)$ & $0.6371(5)$ \\
\hline$C(3)^{\prime}$ & $0.3034(4)$ & $0.1980(2)$ & $0.5000(5)$ \\
\hline $\mathrm{C}(4)^{\prime}$ & $0.3834(5)$ & $0.1793(2)$ & $0.4068(5)$ \\
\hline$C(5)^{\prime}$ & $0.4781(4)$ & $0.1383(2)$ & $0.4464(4)$ \\
\hline $\mathrm{C}(2)^{\prime \prime}$ & $0.8073(4)$ & $0.0893(2)$ & $0.5791(5)$ \\
\hline $\mathrm{C}(3)^{\prime \prime}$ & $0.9372(5)$ & $0.0996(2)$ & $0.6305(7)$ \\
\hline $\mathrm{C}(4)^{\prime \prime}$ & $0.9797(4)$ & $0.0981(2)$ & $0.7727(7)$ \\
\hline$C(5)^{\prime \prime}$ & $0.8948(4)$ & $0.0887(2)$ & $0.8693(6)$ \\
\hline $\mathrm{C}(2)^{\prime \prime \prime}$ & $0.6975(4)$ & $0.1429(2)$ & $1.0965(5)$ \\
\hline$C(3)^{\prime \prime \prime}$ & $0.6485(5)$ & $0.1884(2)$ & $1.1580(5)$ \\
\hline $\mathrm{C}(4)^{\prime \prime \prime}$ & $0.5280(5)$ & $0.2086(2)$ & $1.1087(5)$ \\
\hline$C(5)^{\prime \prime \prime}$ & $0.4518(5)$ & $0.1819(2)$ & $0.9976(5)$ \\
\hline \multicolumn{4}{|c|}{ Complex 4} \\
\hline $\mathrm{Cr}$ & $0.40665(6)$ & $0.58249(9)$ & $0.6935(2)$ \\
\hline $\mathrm{O}(1)$ & $0.4425(3)$ & $0.5853(6)$ & $0.3334(7)$ \\
\hline $\mathrm{O}(2)$ & $0.3521(4)$ & $0.7688(5)$ & $0.642(1)$ \\
\hline$O(3)$ & $0.5328(4)$ & $0.6641(7)$ & $0.771(1)$ \\
\hline$C(1)$ & $0.3090(4)$ & $0.4329(5)$ & $0.487(1)$ \\
\hline $\mathrm{C}(2)$ & $0.2823(3)$ & $0.3376(5)$ & $0.5001(9)$ \\
\hline $\mathrm{C}(7)$ & 0.250000 & $0.5549(7)$ & $0.646(1)$ \\
\hline $\mathrm{C}(8)$ & $0.3103(4)$ & $0.5277(5)$ & $0.7333(9)$ \\
\hline $\mathrm{C}(9)$ & $0.3436(3)$ & $0.4623(5)$ & $0.643(1)$ \\
\hline$C(10)$ & 0.250000 & $0.4995(7)$ & $0.477(1)$ \\
\hline $\mathrm{C}(11)$ & 0.250000 & $0.5590(9)$ & $0.325(2)$ \\
\hline $\mathrm{C}(18)$ & $0.4294(4)$ & $0.5832(7)$ & $0.474(1)$ \\
\hline $\mathrm{C}(19)$ & $0.4844(5)$ & $0.6322(8)$ & $0.741(1)$ \\
\hline $\mathrm{C}(20)$ & $0.3748(5)$ & $0.6983(6)$ & $0.664(1)$ \\
\hline $\mathrm{C}(2)^{\prime}$ & $0.3161(4)$ & $0.2550(7)$ & $0.512(1)$ \\
\hline $\mathrm{C}(3)^{\prime}$ & $0.2825(5)$ & $0.1749(6)$ & $0.528(1)$ \\
\hline $\mathrm{C}(2)^{\prime \prime \prime}$ & $0.3333(4)$ & $0.5625(5)$ & $0.8856(9)$ \\
\hline$C(3)^{\prime \prime \prime}$ & $0.3907(4)$ & $0.5299(6)$ & $0.947(1)$ \\
\hline$C(4)^{\prime \prime \prime}$ & $0.4245(4)$ & $0.4627(6)$ & $0.860(1)$ \\
\hline $\mathrm{C}(5)^{\prime \prime \prime}$ & $0.4022(4)$ & $0.4295(5)$ & $0.704(1)$ \\
\hline \multicolumn{4}{|c|}{ Complex 5} \\
\hline $\operatorname{Cr}(1)$ & $0.50456(5)$ & $0.36319(3)$ & $0.81774(6)$ \\
\hline $\operatorname{Cr}(2)$ & $0.50516(4)$ & $0.01600(3)$ & $0.78987(5)$ \\
\hline $\operatorname{Cr}(3)$ & $0.69826(5)$ & $0.25284(3)$ & $0.51445(6)$ \\
\hline $\mathrm{O}(1)^{\prime}$ & $0.6852(2)$ & $-0.0170(2)$ & $1.0065(3)$ \\
\hline $\mathrm{O}(2)^{\prime}$ & $0.4027(3)$ & $-0.1258(2)$ & $0.8319(4)$ \\
\hline$O(3)^{\prime}$ & $0.6173(3)$ & $-0.0729(2)$ & $0.6735(3)$ \\
\hline$O(1)$ & $0.3215(3)$ & $0.4429(4)$ & $0.8174(4)$ \\
\hline $\mathrm{O}(2)$ & $0.3598(3)$ & $0.2619(2)$ & $0.6346(3)$ \\
\hline$O(3)$ & $0.4775(4)$ & $0.4654(3)$ & $0.6133(5)$ \\
\hline $\mathrm{O}(1)^{\prime \prime}$ & $0.9159(3)$ & $0.2809(3)$ & $0.6454(5)$ \\
\hline $\mathrm{O}(2)^{\prime \prime}$ & $0.7279(4)$ & $0.2771(3)$ & $0.2894(4)$ \\
\hline $\mathrm{O}(3)^{\prime \prime}$ & $0.7523(4)$ & $0.0858(2)$ & $0.5279(4)$ \\
\hline
\end{tabular}


Table 6 (continued)

\begin{tabular}{|c|c|c|c|}
\hline Atom & $x$ & $y$ & $z$ \\
\hline$C(1)$ & $0.7077(3)$ & $0.2711(2)$ & $0.7936(3)$ \\
\hline $\mathrm{C}(2)$ & $0.6618(3)$ & $0.3172(2)$ & $0.8644(3)$ \\
\hline$C(3)$ & $0.6137(3)$ & $0.2675(2)$ & $0.9168(3)$ \\
\hline $\mathrm{C}(4)$ & $0.6271(3)$ & $0.1838(2)$ & $0.8916(3)$ \\
\hline$C(5)$ & $0.5305(3)$ & $0.1420(2)$ & $0.8227(3)$ \\
\hline$C(6)$ & $0.5229(3)$ & $0.1266(2)$ & $0.7079(3)$ \\
\hline$C(7)$ & $0.6143(2)$ & $0.1534(2)$ & $0.6888(3)$ \\
\hline$C(8)$ & $0.5991(2)$ & $0.2211(2)$ & $0.6061(3)$ \\
\hline $\mathrm{C}(9)$ & $0.6563(3)$ & $0.2859(2)$ & $0.6637(3)$ \\
\hline$C(10)$ & $0.6878(3)$ & $0.1849(2)$ & $0.8114(3)$ \\
\hline$C(11)$ & $0.7831(3)$ & $0.1368(2)$ & $0.8605(4)$ \\
\hline$C(12)$ & $0.3912(4)$ & $0.4102(3)$ & $0.8199(4)$ \\
\hline$C(13)$ & $0.4174(3)$ & $0.2970(2)$ & $0.7073(4)$ \\
\hline$C(14)$ & $0.4873(4)$ & $0.4256(3)$ & $0.6910(5)$ \\
\hline$C(15)$ & $0.6145(3)$ & $-0.0042(2)$ & $0.9255(4)$ \\
\hline$C(16)$ & $0.4423(3)$ & $-0.0733(2)$ & $0.8131(4)$ \\
\hline$C(17)$ & $0.5722(3)$ & $-0.0400(2)$ & $0.7169(3)$ \\
\hline$C(18)$ & $0.8309(4)$ & $0.2710(3)$ & $0.5938(5)$ \\
\hline$C(19)$ & $0.7168(4)$ & $0.2666(3)$ & $0.3755(5)$ \\
\hline$C(20)$ & $0.7317(4)$ & $0.1505(3)$ & $0.5176(5)$ \\
\hline $\mathrm{C}(2)^{\prime}$ & $0.6636(3)$ & $0.3972(2)$ & $0.8849(4)$ \\
\hline$C(3)^{\prime}$ & $0.6202(3)$ & $0.4263(2)$ & $0.9599(4)$ \\
\hline$C(4)^{\prime}$ & $0.5705(4)$ & $0.3778(3)$ & $1.0087(4)$ \\
\hline$C(5)^{\prime}$ & $0.5660(3)$ & $0.2969(2)$ & $0.9888(3)$ \\
\hline $\mathrm{C}(2)^{\prime \prime}$ & $0.4532(3)$ & $0.1192(2)$ & $0.8585(4)$ \\
\hline$C(3)^{\prime \prime}$ & $0.3701(3)$ & $0.0808(2)$ & $0.7802(4)$ \\
\hline$C(4)^{\prime \prime}$ & $0.3624(3)$ & $0.0643(2)$ & $0.6654(4)$ \\
\hline$C(5)^{\prime \prime}$ & $0.4396(3)$ & $0.0859(2)$ & $0.6293(3)$ \\
\hline$C(2)^{\prime \prime \prime}$ & $0.5405(3)$ & $0.2235(2)$ & $0.4855(4)$ \\
\hline$C(3)^{\prime \prime \prime}$ & $0.5424(3)$ & $0.2922(3)$ & $0.4238(4)$ \\
\hline$C(4)^{\prime \prime \prime}$ & $0.6017(4)$ & $0.3558(2)$ & $0.4810(4)$ \\
\hline$C(5)^{\prime \prime \prime}$ & $0.6585(3)$ & $0.3531(2)$ & $0.5996(4)$ \\
\hline
\end{tabular}

Table 7 Some idealized torsion angles $/^{\circ}$ about the normal to the complexed benzene ring passing through the $\mathrm{Cr}$ atoms

\begin{tabular}{lrrr}
\hline & \multicolumn{3}{l}{ Complex } \\
\cline { 2 - 4 } & \multicolumn{1}{c}{$\mathbf{3}$} & \multicolumn{4}{c}{} & \multicolumn{1}{c}{$\mathbf{5}$} \\
\hline$C(3)-\varphi^{\prime}(1)-\operatorname{Cr}(1)-C(13)^{a}$ & 2.0 & - & 0.0 \\
$C(5)-\varphi^{\prime \prime}(2)-\operatorname{Cr}(2)-C(15)$ & 17.5 & 20.1 & 18.5 \\
$C(8)-\varphi^{\prime \prime \prime}(3)-C r(3)-C(20)$ & \multicolumn{1}{c}{-} & 20.1 & 20.0 \\
\hline
\end{tabular}

${ }^{a} \varphi^{\prime}, \varphi^{\prime \prime}$ and $\varphi^{\prime \prime \prime}$ indicate the location of the centre of the corresponding benzene ring (see Fig. 1).

$\left[\mathrm{M}^{+}-(\mathrm{Cr}, 5 \mathrm{CO}), 6.8\right], 346\left[\mathrm{M}^{+}-(\mathrm{Cr}, 6 \mathrm{CO}), 100\right], 294$ $\left[\mathrm{M}^{+}-(2 \mathrm{Cr}, 6 \mathrm{CO}), 10.7\right]$ and $52\left(\mathrm{Cr}^{+}, 3.5\right)$.

Complex 4. M.p. $220^{\circ} \mathrm{C}$ (decomp.); $v_{\max }(\mathrm{THF}) / \mathrm{cm}^{-1} 1969 \mathrm{vs}$, $1958 \mathrm{vs}, 1894 \mathrm{vs}$ and $1889 \mathrm{vs}(\mathrm{C} \equiv \mathrm{O}) ; \mathrm{m} / \mathrm{z} 566\left(\mathrm{M}^{+}, 13.4\right), 510$ $\left(\mathrm{M}^{+}-2 \mathrm{CO}, 4.3\right), 482\left(\mathrm{M}^{+}-3 \mathrm{CO}, 29.0\right), 454\left(\mathrm{M}^{+}-4 \mathrm{CO}\right.$, 6.0), $430\left[\mathrm{M}^{+}-(\mathrm{Cr}, 3 \mathrm{CO}), 3.2\right], 426\left(\mathrm{M}^{+}-5 \mathrm{CO}, 32.4\right), 398$ $\left(\mathrm{M}^{+}-6 \mathrm{CO}, 25.5\right), 374\left[\mathrm{M}^{+}-(\mathrm{Cr}, 5 \mathrm{CO}), 5.7\right], 346\left[\mathrm{M}^{+}-\right.$ $(\mathrm{Cr}, 6 \mathrm{CO}), 100], 294\left[\mathrm{M}^{+}-(2 \mathrm{Cr}, 6 \mathrm{CO}), 6.6\right]$ and $52\left(\mathrm{Cr}^{+}\right.$, $55.1)$.

Complex 5. M.p. $220^{\circ} \mathrm{C}$ (decomp.); $v_{\max }(\mathrm{THF}) / \mathrm{cm}^{-1} 1969 \mathrm{vs,}$ $1962 \mathrm{vs}, 1957 \mathrm{vs}, 1894 \mathrm{vs}$ and $1882 \mathrm{vs}(\mathrm{C} \equiv \mathrm{O}) ; \mathrm{m} / \mathrm{z} 702\left(\mathrm{M}^{+}, 5.3 \%\right)$, $618\left(\mathrm{M}^{+}-3 \mathrm{CO}, 5.8\right), 590\left(\mathrm{M}^{+}-4 \mathrm{CO}, 6.1\right), 566\left[\mathrm{M}^{+}-(\mathrm{Cr}\right.$, $3 \mathrm{CO}), 4.3], 562\left(\mathrm{M}^{+}-5 \mathrm{CO}, 6.8\right), 534\left(\mathrm{M}^{+}-6 \mathrm{CO}, 7.5\right), 510$ $\left[\mathrm{M}^{+}-(\mathrm{Cr}, 5 \mathrm{CO}), 2.8\right], 506\left(\mathrm{M}^{+}-7 \mathrm{CO}, 2.4\right), 482\left[\mathrm{M}^{+}-\right.$ $(\mathrm{Cr}, 6 \mathrm{CO}), 22.4], 478\left(\mathrm{M}^{+}-8 \mathrm{CO}, 2.7\right), 454\left[\mathrm{M}^{+}-(\mathrm{Cr}\right.$, 7CO $), 4.8], 450\left(\mathrm{M}^{+}-9 \mathrm{CO}, 9.2\right), 426\left[\mathrm{M}^{+}-(\mathrm{Cr}, 8 \mathrm{CO})\right.$, $11.7], 398\left[\mathrm{M}^{+}-(\mathrm{Cr}, 9 \mathrm{CO}), 14.3\right], 374\left[\mathrm{M}^{+}-(2 \mathrm{Cr}, 8 \mathrm{CO})\right.$, $3.1], 346\left[\mathrm{M}^{+}-(2 \mathrm{Cr}, 9 \mathrm{CO}), 100\right], 294\left[\mathrm{M}^{+}-(3 \mathrm{Cr}, 9 \mathrm{CO})\right.$, $8.8]$ and $52\left(\mathrm{Cr}^{+}, 61.6\right)$.

* For details of CCDC deposition scheme, see 'Instructions for Authors (1991), J. Chem. Soc., Perkin Trans. 2, 1991, Issue 1.
Table 8 Dihedral angles $/{ }^{\circ}$ between the mean planes defined by the three indan moieties on $\mathrm{MTBQ}^{a}$

\begin{tabular}{llll}
\hline & \multicolumn{3}{l}{ Complex } \\
\cline { 2 - 4 } & $\mathbf{3}$ & $\mathbf{4}$ & $\mathbf{5}$ \\
\hline & & & \\
\hline$\alpha \beta \gamma$ & 126.0 & 115.5 & 123.1 \\
$\angle \beta \gamma$ & 121.7 & 115.5 & 116.2 \\
& 119.2 & 122.0 & 125.5 \\
\hline
\end{tabular}

${ }^{a} \alpha, \beta$ and $\gamma$ refer to the indan moiety complexed with $\mathrm{Cr}(1), \mathrm{Cr}(2)$ and $\mathrm{Cr}(3)$, respectively. The equations of these planes are deposited as supplementary material.

Complex 6. M.p. $215^{\circ} \mathrm{C}$ (decomp.); $v_{\max }(\mathrm{THF}) / \mathrm{cm}^{-1} 1978 \mathrm{vs,}$ $1971 \mathrm{vs}, 1963 \mathrm{~s}, 1899 \mathrm{vs}$ and $1892 \mathrm{vs}(\mathrm{C} \equiv \mathrm{O}) ; \mathrm{m} / \mathrm{z} 702\left(\mathrm{M}^{+}, 6.9 \%\right)$, $618\left(\mathrm{M}^{+}-3 \mathrm{CO}, 14.3\right), 566\left[\mathrm{M}^{+}-(\mathrm{Cr}, 3 \mathrm{CO}), 7.4\right], 534$ $\left(\mathrm{M}^{+}-6 \mathrm{CO}, 18.2\right), 506\left(\mathrm{M}^{+}-7 \mathrm{CO}, 13.1\right), 482\left[\mathrm{M}^{+}-(\mathrm{Cr}\right.$, 6CO), 17.7], $450\left(\mathrm{M}^{+}-9 \mathrm{CO}, 19.7\right), 426\left[\mathrm{M}^{+}-(\mathrm{Cr}, 8 \mathrm{CO})\right.$, $20.7], 398\left[\mathrm{M}^{+}-(\mathrm{Cr}, 9 \mathrm{CO}), 19.2\right], 374\left[\mathrm{M}^{+}-(2 \mathrm{Cr}, 8 \mathrm{CO})\right.$, $7.4], 346\left[\mathrm{M}^{+}-(2 \mathrm{Cr}, 9 \mathrm{CO}), 100\right], 294\left[\mathrm{M}^{+}-(3 \mathrm{Cr}, 9 \mathrm{CO})\right.$, 17.3] and $52\left(\mathrm{Cr}^{+}, 89.3\right)$.

Collection of NMR Data.-20-40 $\mathrm{mmol} \mathrm{dm}^{-3}$ suitable solutions for both ${ }^{1} \mathrm{H}$ and ${ }^{13} \mathrm{C}$ NMR measurements have been obtained by using carefully dried, oxygen-free $\left[{ }^{2} \mathrm{H}_{6}\right]$ acetone. The proton spectra, recorded on a Bruker AM400 spectrometer operating an $400.13 \mathrm{MHz}$, were analysed using the Bruker PANIC program on a Bruker Aspect 2000 computer. The proton-decoupled $100.614 \mathrm{MHz}{ }^{13} \mathrm{C}$ NMR spectra were obtained on the same solutions by using a $6 \mathrm{~s}$-delayed Waltz-like CPD decoupling technique with full recover of the Overhauser line enhancement to obtain satisfactory signal-to-noise ratios after $128-256$ accumulations on a $64 \mathrm{~K}$ point size.

Collection of X-Ray Diffraction Data.-Single crystals of 3, 4 and 5 were grown under argon from a saturated solution in a $1: 1: 1$ mixture of acetone, methanol and methylene chloride. They were mounted on a Philips PW-100 computer-controlled four-cycle diffractometer with graphite monochromator. Standard centring and autoindexing procedures ${ }^{14}$ indicated a primitive orthorhombic lattice, space group Pmcn for 4 and primitive monoclinic lattices, space group $P 2_{1} / n$, for both 3 and 5. The orientation matrix and accurate unit cell dimensions were determined from a least-square fit of 25 symmetry-related reflections. The intensities were corrected for Lorentz and polarization effects but not for absorption owing to the relative low $\mu$ values. Crystal data and details of the intensity data collection appear in Table 4. The positions of the $\mathrm{Cr}$ atoms were determined from three-dimensional Patterson syntheses. The light atoms were located from subsequent Fourier maps. Calculated $\mathrm{H}$-atom positions $(\mathrm{C}-\mathrm{H}=1.0 \AA$ ) were used in structure factor calculations but not refined. Anisotropic thermal parameters were used for all the non-hydrogen atoms. Blocked-cascade least-square refinements were used; they converged to the conventional $R$ indexes reported in Table 4 . A unitary weighting scheme was used. Scattering factors for the atoms were taken from Cromer and Waber, ${ }^{15}$ the scattering factors for $\mathrm{Cr}$ were corrected for the real and imaginary parts of anomalous dispersion using Cromer's values. ${ }^{16}$ All computations were carried out on a Cyber 76 computer using the SHELX-76 program. ${ }^{17}$ The final positional parameters of the non-hydrogen atoms are listed in Table 6. Tables of anisotropic thermal parameters of the non-hydrogen atoms, the positional parameters of hydrogen atoms, a full list of bond lengths and angles and the equations of least-square planes have been deposited at the Cambridge Crystallographic Data Centre.* 


\section{Acknowledgements}

This work was supported in part by the National Research Council of Italy (CNR) through its Centro di Studio sugli Stati Molecolari, Radicalici ed Eccitati. Support by the Deutsche Forschungsgemeinschaft (DFG, $\mathrm{Ku} \mathrm{6631-1)} \mathrm{is} \mathrm{gratefully}$ acknowledged.

\section{References}

1 (a) R. P. A. Sneeden, Organochromium Compounds, Academic Press Inc., New York, 1975; (b) W. E. Silverthorn, Adv. Organomet. Chem., 1975, 13, 48; (c) M. F. Semmelhack, G. R. Clark, J. L. Garcia, J. J. Harrison, W. Wulff, Y. Tebtaranonth and A. Yamashita, Tetrahedron, 1980, 37, 3957; (d) S. G. Davies, Organotransition Metal Chemistry: Application to Organic Synthesis, Pergamon Press, Oxford, 1982; (e) R. Davies and L. A. P. Kane-Maguire, Chromium Compounds with $\eta^{2}-\eta^{8}$ Carbon Ligands, in Comprehensive Organometallic Chemistry, eds. G. Wilkinson, F. G. A. Stone and E. W. Abel, Pergamon Press, New York, 1982, vol. 3, p. 954.

2 E. P. Kündig, V. Desobry, D. P. Simmons and E. Wenger, J. Am. Chem. Soc., 1989, 111, 1804, and references therein.

3 A. Ceccon, A. Gambaro, F. Gottardi, S. Santi, A. Venzo and V. Lucchini, J. Organomet. Chem., 1989, 379, 67, and preceding papers of the series.

4 G. Gillois, G. Jaouen, D. Buisson and R. Azerad, J. Organomet. Chem., 1989, 367, 85, and references therein.

5 R. U. Kirss, P. M. Treichel and K. J. Haller, Organometallics, 1987, 6, 242 , and references therein.

6 T. E. Bitterwolf, R. Herzog and P. D. Rockswold, J. Organomet. Chem., 1987, 320, 197.
7 T. G. Traylor, M. J. Goldberg and A. R. Miksztal,' Organometallics, $1989,8,1101$

8 D. Kuck, Angew. Chem., Int. Ed. Engl., 1984, 23, 508.

9 (a) D. Kuck, in Quasicrystals, Networks, and Molecules of Fivefold Symmetry, ed. I. Hargittai, VCH Publishers, New York 1990; ch. 19; (b) D. Kuck, to be published.

10 R. D. Rogers, J. L. Atwood, T. A. Albright, W. A. Lee and M. D. Rausch, Organometallics, 1984, 3, 263.

11 See refs. 6-8 in ref. 7.

12 D. Kuck, H. Bögge, M. Penk, B. Paisdor and A. Müller, manuscript in preparation.

13 T. E. Bitterwolf, A. Ceccon, F. Manoli, A. Venzo, P. Ganis and G Valle, XII European Crystallographic Meeting, Moscow (USSR), August 20-29, 1989; Abstracts, vol. 2, p. 202; A. Ceccon, A. Gambaro, A. Venzo and D. Kuck, Federation of the European Chemical Societies, VII FECHEM Conference on Organometallic Chemistry, Veszprèm-Balatonfüred (Hungary); Abstracts, p. P-142.

14 R. A. Sparks, in Crystallographic Computing Techniques, ed. F. R. Ahmed, Munksgaard, Copenhagen, 1976, p. 452.

15 D. T. Cromer and J. T. Waber, Acta Crystallogr., 1965, 18, 184.

16 D. T. Cromer, Acta Crystallogr., 1965, 18, 17.

17 G. M. Sheldrick, SHELX-76 Program for Crystal Structure Determination; Cambridge University, England, 1976.
Paper 0/03479G

Received 31 st July 1990 Accepted 19th September 1990 